Hydroécol. Appl. (1993) Tome 5 Vol. 2, pp. 7-26

\title{
The Enhancement of Drained Salmonid Rivers in Ireland - A Bioengineering Perspective
}

\section{La mise en valeur des rivières à saumons d'Irlande soumises à des captages. Notion de bioingénierie}

\author{
Martin F. O'Grady, John Curtin
}

Central Fisheries Board, Mobhi Boreen, Glasnevin, Dublin 9, Ireland

Office of Public Works, Newtown, Trim, Co. Meath, Ireland.

Summary. - The authors, a fisheries biologist and drainage engineer have been involved in enhancing drained salmonid rivers in Ireland over the last decade. Our objective has been to increase the extent of productive salmon (Salmo salar L.) and trout (Salmo trutta L.) water in rivers which have been subjected to arterial drainage schemes. This paper draws on the experience of the authors to describe, with hindsight, how one should ideally plan such a study from the drainage design phase through to the postdrainage fisheries enhancement programme.

Such a programme must be regarded as a bio-engineering exercise if it is to prove successful. Information required in this area will include detail in relation to channel and bank substrate types, a longitudinal profile of all channels, bank heights and hydrographs. In relation to the latter area particular attention should be paid to both peak flood, mean $(x)$ and minimum low flow discharges.

The fisheries biologist should ideally compile a detailed ecological profile of the catchment encompassing information on bankside and instream vegetation, macroinvertebrate fauna and fish numbers with particular reference to defining the extent to which, and the reasons why, particular channel lenghts function effectively as salmonid spawning, nursery or adult areas.

When the drainage scheme is being designed, the biologist, using the aforementioned data base, should examine the proposals, at draft stage, with a view to adjusting same to the advantage of fishery interests.

The various ways in which the pre-drainage bio-engineering data base can be used to minimise the impact of drainage and hasten recovery are described.

Ideally, post-drainage, most instream physical works designed for fisheries enhancement should not be undertaken for two years after the dredging is completed. The logic for this approach is outlined.

Some of the physical enhancement works programmes undertaken by the authors are outlined and their relative success is documented. Collaborative bio-engineering ventures in relation to minimising the ecological impact of drainage design are also discussed. 
The objectives of the drainage engineer and the fisheries biologist are very different. However, the authors would contend that the co-operation of both disciplines in this area can help to minimise the disruptive influence of drainage programmes and, thereafter, restore the productivity of channels in fisheries terms.

\section{Key words. - Salimonid - Bioengineering - Enhancement - Ireland.}

Résumé. - Les auteurs, un biologiste des pêches et un ingénieur hydraulicien ont été engagés dans la mise en valeur des rivières à saumons soumises à des captages au cours des dix dernières années. L'objectif a été d'accroître l'importance de la production de saumon (Salmo salar L.) et de truite (Salmo trutta L.) des rivières soumises à d'importants travaux de captage. Cet article, basé sur l'expérience des auteurs, décrit avec objectivité, comment on devrait planifier de façon idéale une étude, de la phase de projet du captage jusqu'au programme de mise en valeur des pêcheries après la réalisation des travaux.

Un tel programme doit être considéré comme un exercice de bioingénierie si l'on veut que ce soit un succès. Les informations nécessaires incluront les relations précises entre les types de substrat du lit de la rivière et les berges, un profil longitudinal de tous les lits, la hauteur des rives et les courbes de débit. Pour ce dernier point, une attention particulière devrait être portée à la fois sur le pic des débits, la moyenne $(x)$ et le plus bas débit prélevé.

Le biologiste des pêches devrait rassembler le maximum d'informations écologiques concernant le bassin versant incluant la végétation rivulaire et aquatique, la faune de macroinvertébrés et des poissons; une référence particulière devrait porter sur les tronçons de cours d'eau concernès par les frayères, les alevins et les adultes de salmonidés. Quant l'étude du captage est projetée, le biologiste, utilisant la base de données mentionnées ci-dessus, devrait examiner les propositions aux différentes étapes, dans l'optique d'apporter quelques améliorations intéressantes pour les peuplements de poissons. Les diverses propositions destinées à minimiser l'impact des captages et accélérer le retour à la normale sont décrites.

Quelques-uns des programmes de mise en valeur relatifs aux paramètres physiques entrepris par les auteurs sont soulignés et leur succès relatif est détaillé. Les objectifs des ingénieurs hydrauliciens et les biologistes des pêches sont très différents. Pourtant, les auteurs tendent à prétendre que la coopération entre les deux disciplines, dans ce domaine, peut minimiser l'influence disruptive des programmes de captage et donc peut permettre de restaurer la productivité des cours d'eau du point de vue des pêches.

Mots-clés: Salmonidés - Bioingénierie - Mise en valeur - Irlande.

\section{INTRODUCTION}

Arterial drainage progammes have been carried out on many of Ireland's riverine catchments over the last century. Most major schemes have been undertaken since the 1950's by the Office of Public Works under the
1945 Arterial Drainage Act. Being primarily an agricultural country there was a significant emphasis on land drainage. The twin objectives of these drainage schemes were to limit flooding and lower the water table thereby bringing "marginal" lands into the productive agricultural sector. Most of 
these drainage schemes involved a dredging of channels both vertically and horizontally to achieve the desired objectives. A small number of embanked schemes were undertaken. A limited number of partial drainage schemes were undertaken from the late 1800's to 1950. Subsequently many of Ireland's major catchments were subjected to arterial drainage from 1950 to 1985 (fig. 1). Fish stocks in virtually all of the drained river catchements in question are dominated by salmonids. There are two indigenous species in question, atlantic salmon (Salmo salar L.) and brown trout (Salmo trutta L.). The watersheds in question have drainage basin areas up to $4,375 \mathrm{~km}^{2}$. Channel gradients in the main channels and first order tributaries of these catchements are generally within the range $0.05 \%$ to $0.3 \%$ (fig. 2 ).

Since the 1980's there has been an increased recognition in Ireland that its salmonid riverine catchments are a valuable natural resource and a significant source of tourist revenue (Whelan and Marsh, 1988). Unlike many European nations Ireland's riverine catchments continue to function as salmonid waters. For example migratory atlantic salmon stocks, while reduced in numbers in some cases, have not been eliminated in any catchment in Ireland in the last century.

Over the last decade the authors have been involved jointly in undertaking post-drainage fishery enhancement programmes in a number of drained catchments. We have drawn on our experiences in this area to present a strategy, with hindsight, in relation to how drainage engineers and biologists might work together to ensure that the drainage of salmonid catchments will cause the minimum damage to the functioning of these channels from a fisheries perspective. The key elements in each stage of such a strategy are outlined in this paper. Comment is also provided on drainage maintenance in relation to reducing its impact on fisheries. Some of the positive and negative effects of drainage on Irish rivers are also outlined.

\section{THE PLANNING STAGE}

Initially when a catchment is selected for drainage detailed physical, hydrological and agricultural studies are required in order to design the scheme and thereafter a cost benefit analysis can be carried out. Assuming that the latter is favourable and the scheme is to proceed then the physical and hydrological information compiled by the engineers in the course of the planning stage should be used by the biological team as a starting point for their involvement. A schematic outline of the type of information compiled by Irish drainage engineers in the course of their studies is presented (fig. 3). In the authors experience salmonid stock densities in Irish rivers are determined in the first instance by channel gradient and influenced thereafter principally by discharge level, substrate type and the bank cover regime in circumstances where good water 


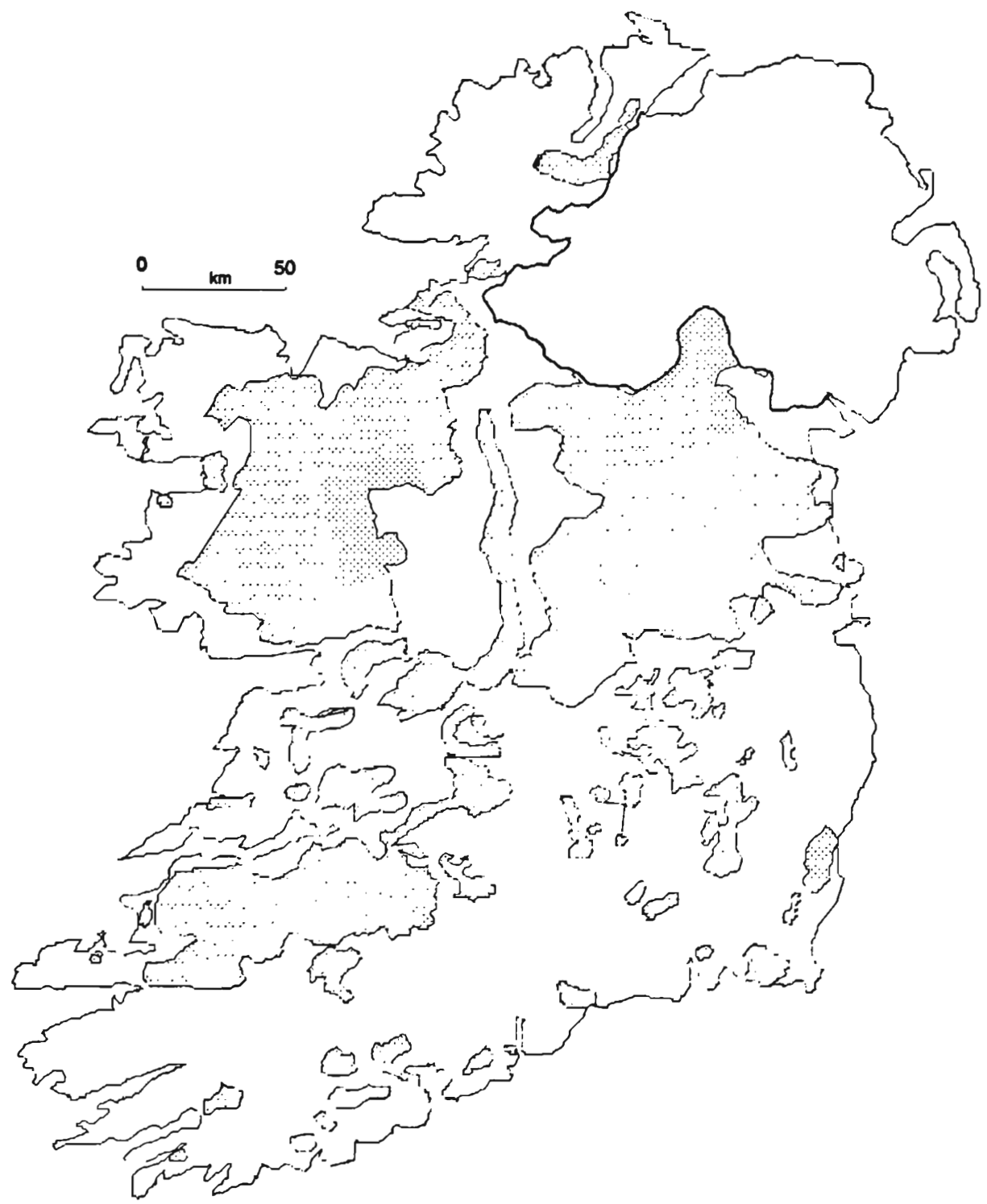

Fig. 1. - The extent of catchments drained in the Republic of Ireland since 1842.

quality is assumed. The importance of these factors in determining the relative size and type of salmonid populations have been recognised by many authors (Rosgen, 1985, Cupp, 1989a, b and many others). The availability of this physical data base allows one to select specific channel 


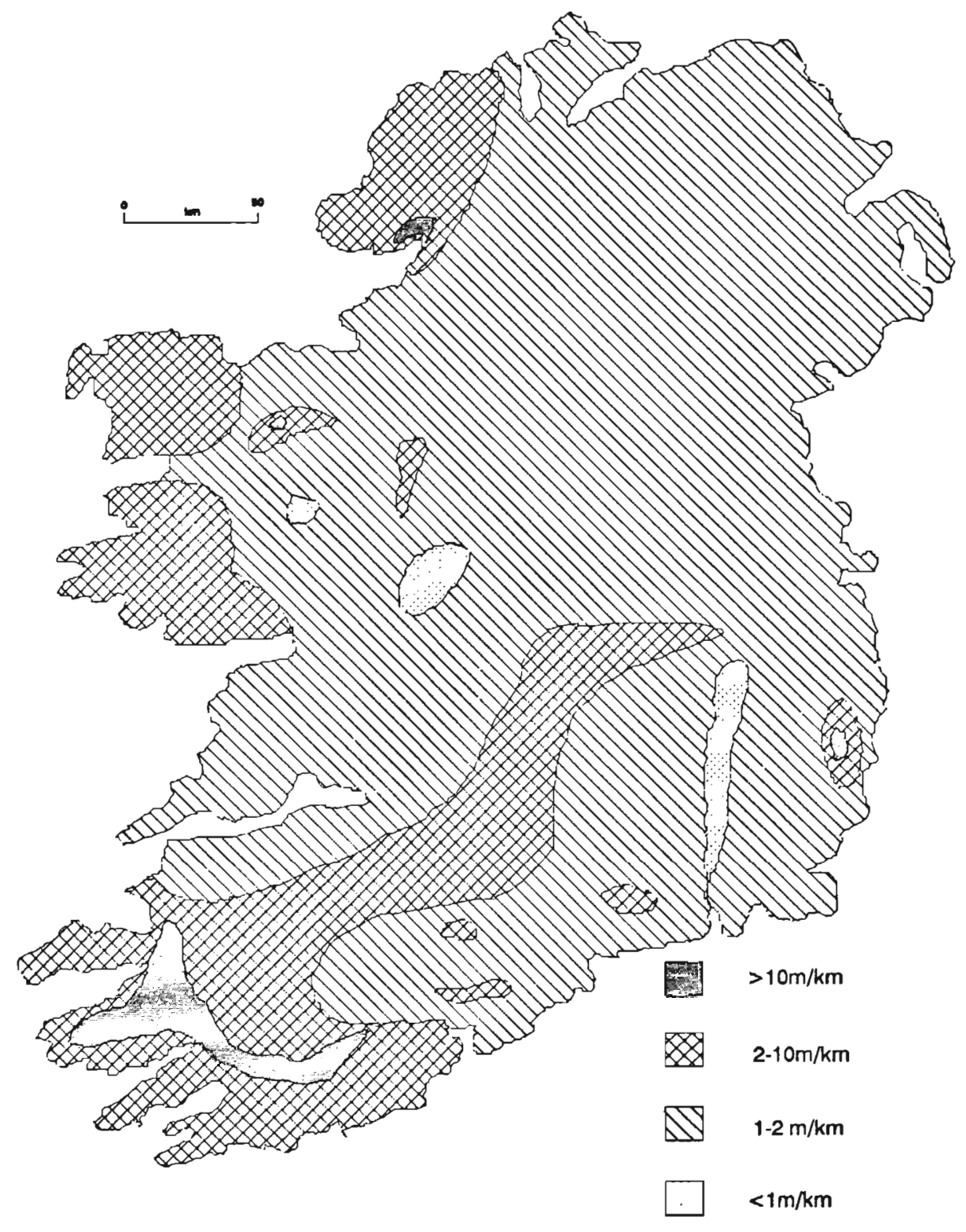

Ireland

Fig. 2. - The general physiography of Ireland. 
sections in all sub-catchments with a particular gradient and substrate type for detailed study, in the knowledge that the areas examined are likely to reflect the situation over long sections of channel where the same physical conditions apply. Such a strategy provides one with a good overview provided there are no significant changes in the nature of the riparian zone within areas of specific grade and substrate type. The author (O'Grady) has noted that stands of deciduous trees which excessively shade channels, reducing the instream aquatic flora, can significantly reduce the standing crop of salmonids at least in the summer/autumn period
(O'Grady, 1993). One therefore needs to take account of such change in designing the sampling programme. The length of channel sampled within any sub-section will ultimately depend on channel morphology. For example if the gradient is such that there is a riffle/glide/pool sequence then the minimum sampling unit should include at least one such sequence. The desirable type and frequency of measurements required within each sampling reach have been described by Binns (1982), Hermansen and Kregs (1984), Petts and Foster (1985), Brooks (1957) and others. Essentially such records enable one to describe each site quantitatively in

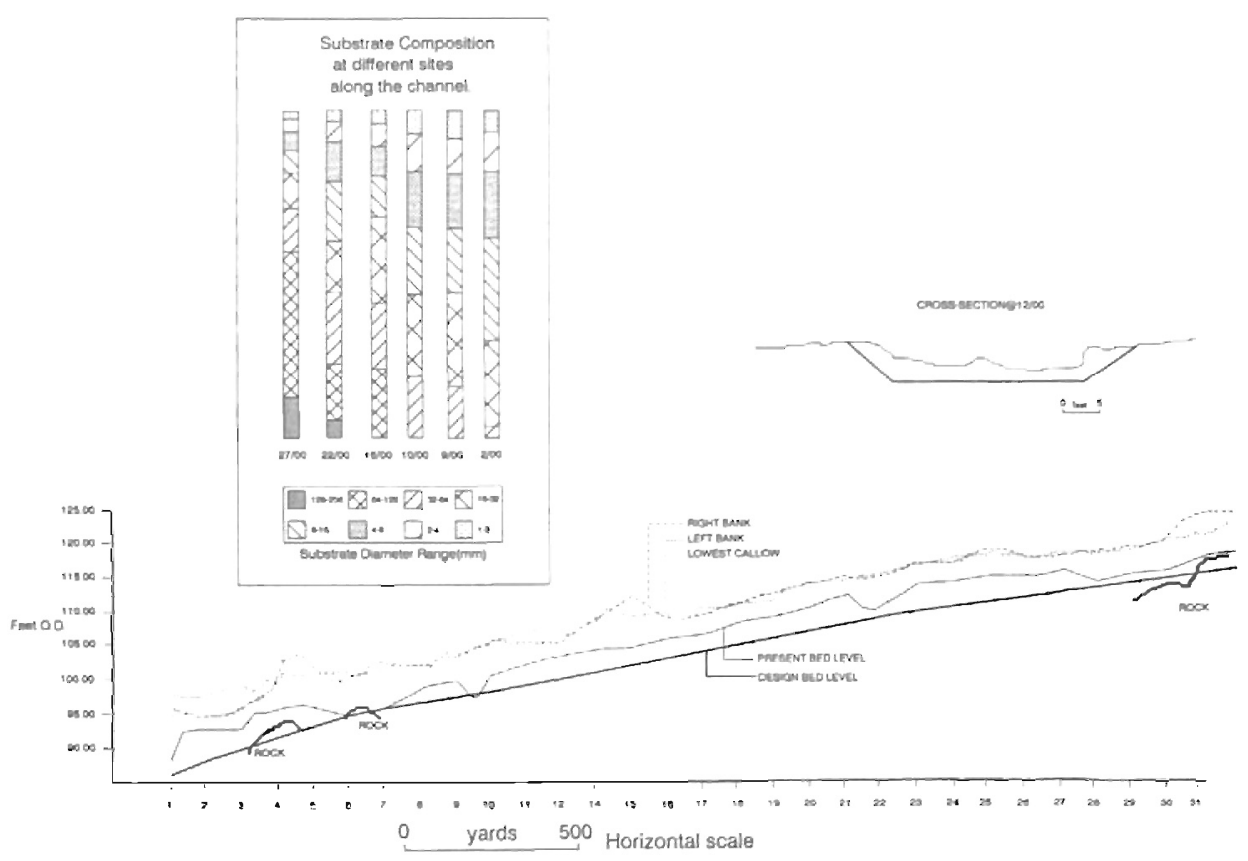

Fig. 3. - An illustration of the type of information compiled by Irish drainage engineers at the pre-drainage planning phase. 
physical and hydraulic terms from the fisheries perspective. Aquatic floristic and macro-invertebrate records are also most desirable as is a description of the riparian zone. Quantitative assessments of salmonid stocks and, where possible, all other fish species are essential. The compilation of this type of data base is essential in understanding how a catchment functions in fisheries terms. An example of the level of sampling required in an Irish catchment $\left(650 \mathrm{~km}^{2}\right)$ to comply with this type of strategy is outlined (fig. 4a) (from O'Grady, 1991(c)) and some of the findings in relation to variation in salmonid habitat and substrate type are illustrated (fig. $4 \mathrm{~b}$ and $\mathrm{c}$ ).

\section{EXAMINATION AND ADJUSTMENT OF DRAINAGE DESIGN PRE-WORKS}

The priorities of the drainage engineers and the fishery biologist are very different. The former is concerned primarily with ensuring that the designed peak discharges are maintained within bank height and outfall is provided for in marginal lands. The fishery biologist is primarily concerned with the ecological conditions in mean summer flow conditions. If the physical and ecological date bases outlined in Section 2 have been compiled it is possible for the engineer and biologist, working in collaboration, to adjust the first phase design to the advantage of fisheries interests. This con- cept is now an accepted part of environmental impact assessment studies (C.E.C., 1978).

The drainage design in engineering terms seeks to find the minimum cost option to achieve the required outfall and discharge objectives. In channels of fishery value, hydraulic data, for mean summer flow levels, should be used to assist in the examination of the likely effects of the drainage design on a fishery. Such calculations may allow one to adjust design, and while still attaining the drainage objectives, reduce the longterm impact on the fishery resource or, at least, create a physical regime which can be rehabilitated post-works. This proposal, while very effective, is likely to result in increased engineering costs. However, these must be weighed against the permanent fishery losses which may otherwise be incurred. There is now widespread recognition of the problems created by not taking cognisance of the importance of retaining many natural features of channels (meanders, bank slope, etc.) when draining rivers (Boon et al., 1992).

Apart from the aforementioned considerations in relation to backwater analysis the baseline physical, hydrological and biological data can be used in a number of ways to adjust the first phase design to the advantage of fishery interests. A few examples of how this can be done in a practical way are outlined here.

The physical data compiled will illustrate the depth of stony deposits on a particular river bed section and 

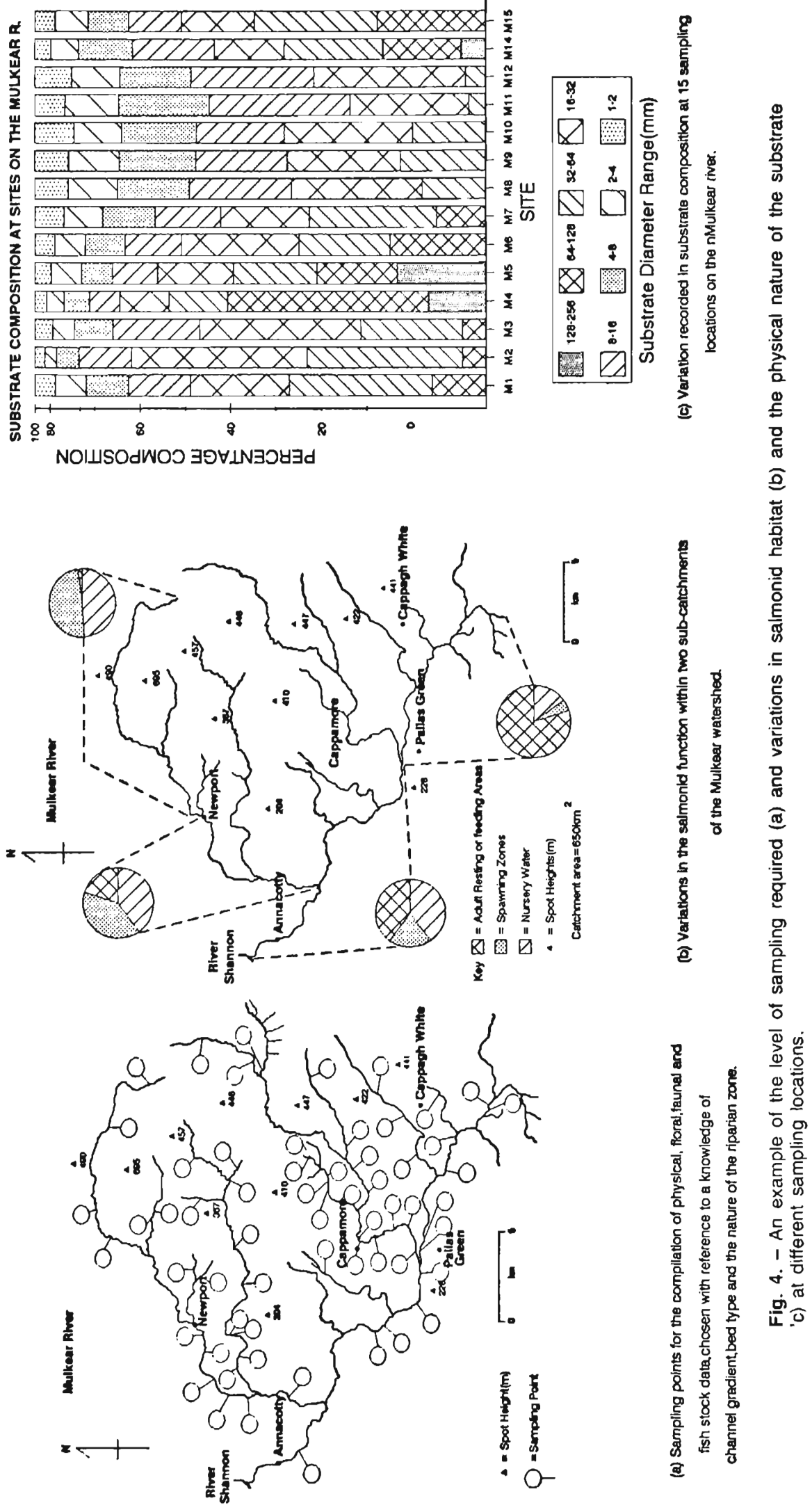
in its banks. A review of the first phase design will determine whether or not the proposed excavation level is likely to alter the substrate type thereby impacting on the ecological regime.

Data on bank materials linked with gradient values will indicate the extent to which erosion might take place post-works and the type of material likely to be washed into the channel. Obviously the erosion of some stony bank materials post-works would be advantageous while a significant increase in sand/silt scour would be disadvantageous. This data base will enable one to assess the relative extent to which bank protection works might be required in specific channel areas.

If the engineering studies indicate that drainage design will necessitate a significant broadening of channel base width the it is imperative that final design facilitate the construction of a "channel within a channel" so that pre-drainage base width at summer levels can be retained within the full drainage base width in order to avoid braiding.

Fishery survey data will also allow one to define the location and extent of salmon and trout angling zones where considerable excavation is planned and provision for angler access post-drainage will be required. Alterations of bankslope design would be considered here with side slopes of $1.5: 1$ being planned. More gently sloping banks providing increased discharge area will also allow for a reduced design base width. Petersen et al. (1992) has shown that reduced side slopes may also reduce longterm maintenance costs.

Drainage will sometimes involve a lowering of bed rock protrusions. In the authors experience the design of the cut through the rock shelf and the nature of the bed post-works will significantly influence its capacity to support salmonids (O'Grady et al., in press). A stepped bed in such circumstances will provide pool areas for trout or provide pockets which can, post-works, be filled with gravels for spawning purposes. In less severe gradients $(<0.3 \%)$ a smooth rock bed covered with a layer of large stones will significantly increase the salmonid carrying capacity and greatly increase the standing crop of macro-invertebrates (Needham, 1969). The placement of rubble on a smooth rock bed may require adjustment of the design bed level and/or base width to accommodate the increased roughness coefficient.

The authors have noted a variation in the light penetration level in Irish rivers which is dictated by water clarity and related to individual catchment characteristics. A significant variation in the euphotic zone in Irish rivers has been noted as a consequence of this phenomenon with aquatic plants being limited to channel bed areas receiving adequate incident light at mean summer low flows. The range of depths at which plants (algae, mosses and macrophytes) can grow in Irish rivers, as observed by the authors, varies from $0.23 \mathrm{~m}$ to $2 \mathrm{~m}$. This generalisation excludes the specialised floating leaved macrophyte 
species such as Nuphar and Potamogeton natans sp. which have been observed growing in deeper water ( $\leq 4 \mathrm{~m}$ ) Caffrey (1990). If, as is likely, a drainage scheme will involve the lowering of river bed high points it is important that biological data compiled in the pre-drainage survey, in relation to the specific maximum depth of the euphotic zone, be taken into account in adjusting the first phase design. The authors have observed a number of situations in drained Irish rivers where, with hindsight, if bed high points had been lowered by an additional $0.5 \mathrm{~m}$ extensive length of channel upstream of these impoundments would have developed a significant flora postworks and became more valuable in a fisheries sense (O'Grady, 1989 and 1991 and O'Grady et al. 1991(a) and O'Grady et al. 1993). This point has now been accepted by Irish drainage engineers in relation to designing future schemes (Howard, 1993).

In a major study of the effects of channelization on bank stabilisation in 46 partially drained rivers in Britain Brookes (1987) has shown that bank erosion is one of the most common problems in the lower undrained reaches of such systems. Pre-drainage physical data in combination with predicted hydrological change post-works should allow one to anticipate such changes and plan for adjustments as required.

Where drainage objectives can be achieved by excavating from one bank only then the disturbance should take place on the north facing bank where possible in order to maintain a channel shade factor. This is particularly important in specific circumstances where channel bed type is particularly suited to colonisation by dense stands of Ranunculus or Potamogeton sp. (fine gravel/sand matrix). Care should be taken to dredge the channel from the north facing banks only where possible to maintain a degree of shade and avoid profuse growths of such plants in the early post-drainage phase. Where channel sections of this type are flowing generally east/west in direction and the removal of the riparian zone on one bank is unavoidable then replanting of the dredged bank should be given an absolute priority. The authors have observed sections of drained channels in Ireland were a treeline on the south facing bank did not regenerate postdrainage resulting in a weed chocked channel in summer flow conditions. Electro-fishing data indicate that, such channels cannot support significant salmonid populations in summertime (O'Grady and Caffrey, 1984).

\section{ACCOMMODATING FISHERIES INTERESTS AT WORKS STAGE}

In studying the effects of drainage on Irish rivers the authors, based on their experience, would make a number of recommendations in this area. 


\section{4a. A Works Schedule In Space and Time}

Studies of the effects of drainage on salmonid stocks in Irish rivers immediately post-works indicate a virtual collapse of fish stocks immediately post-works (Toner et al., 1985; McCarthy, 1977 and 1983). Consequently the works schedule in a catchment where all channels are to be excavated should be designed so that the lower third of each channel of fishery value is excavated first with the machines moving upstream thereafter. The length of excavated channel should be no more than one third of total channel length in any one year. In this way at least some macrophyte and macroinvertebrate recolonisation of dredged areas will take place as the machines move upstream. Consideration should also be given to scheduling works in relation to a whole catchment in an order which will allow some key spawning and nursery grounds and adult trout feeding areas to remain unaltered and functioning in fisheries terms for at least three years while the areas drained initially are recovering. The availability of a comprehensive predrainage census of fish stocks (Section 2 and fig. 4) provides one with a basis for rational planning in this area. Two Irish catchments studied by the authors were drained in such a piecemeal fashion for engineering and logistic reasons. A review of the fluctuations in salmon stocks in both of these watersheds pre-, during, and after works illustrates the advantages of such an approach - a comparison of adult salmon stocks returning to these catchments over the relevant period when compared with geographically adjacent undrained rivers illustrates no significant reduction in salmon numbers as a consequence of works. Investigations have shown that the staggered works programme in these catchments, while not exclusively responsible, has contributed to the maintenance of good salmonid stocks in these catchments during and after works (O'Grady, 1991(a) and O'Grady et al. 1993).

\section{4b. Controlling Silt Loads}

Dredging operations can sometimes generate significant quantities of suspended solids which at works stage, and thereafter, can damage salmonid stocks (Darnell et al., 1976). The physical survey of bed and bank substrates in a catchment pre-drainage and data on channel gradients in combination with hydrological information should allow the engineer to estimate the number and location of silt traps which are likely to be required in any particular channel to limit silt movement. The maintenance of these traps needs to be reviewed regularly at works stage and their continued use may be required in certain areas after works are complete until bank stabilisation is evident.

\section{4c. The Value of Fencing Chan- nels}

In Ireland it was the policy of the drainage board (Office of PublicWorks) to fence off all dredged chan- 
nels after works. In more recent years O.P.W. have also reseeded dredged banks with grasses and replanted trees in addition to fencing. When drainage schemes were completed maintenance of fences became the responsability of individual land owners some of whom maintained these structures while others did not. A review of the riparian zones by the authors along rivers drained in the 1950's and 1960's indicates that where fences were maintained post-works a healthy ecological riparian zone with a continuous treeline and associated marginal flora has reestablished itself without any replanting programme even where both banks had been stripped of all vegetation at works stage. The nature of these treelines varies - in some cases a virtual monoculture of Alder or Willow species has regenerated, while in other circumstances mixed stands of species evident in the surrounding landscape are present. On properties where riverside fences have not been maintained postdrainage and lands have been used for grazing a healthy riparian zone has not regenerated post-drainage often resulting in bankside erosion and bank slippage where livestock have ready access. These observations clearly illustrate that the fencing of channels should be an integral part of drainage operations at works stage. The value of maintaining an undisturbed riparian zone, in both fisheries and general wildlife terms, even in undrained channels has been highlighted by many authors (Waters, 1968, Hynes, 1970, Karr and Schlosser, 1978 and others).

\section{4d. Retention of Excavated Bed Materials}

Significant quantities of stone materials may be required to carry out the post-drainage fisheries rehabilitation programme. It is suggested that the material from bedrock areas and spawning gravels excavated in the course of drainage works be retained for this purpose where possible to reduce costs.

\section{POST-DRAINAGE FISHERIES REHABILITATION PROGRAMMES}

\section{5a. A Strategy}

Apart from the bank fencing, reseeding and planting programme it is recommended that physical in-stream fishery rehabilitation works be delayed for two years post-drainage for the following reasons. While backwater analysis allows one to predict the likely effects of the drainage programme, the recovery of the channel is dependant on a number of ecological, physical and hydrological factors which may interact in unforseen ways post-works.

Modifications to drainage design may be required at works stage to accommodate other public or private interests e.g. abstractions or local amenity parks. Consequently the exact nature of the works schedule and its effects on the channel in physical terms cannot always be anticipated. 
More or less gravel may be exposed by works than one had anticipated. For example in one Irish drainage scheme the works programme resulted in a $17 \%$ increase in the length of gravelled channel in a large catchment, a factor which was not anticipated (O'Grady, 1991(a)).

The extent to which materials will erode into the channel is difficult to judge. Two years post-works the relative stability of banks should be evident, allowing one to make some assessment of what the longterm contribution of bank erosion to channel morphology is likely to be in terms of sand, gravels and stone materials. Irrespective of the efficiency of ones silt entrapment procedures at works stage there is likely to be an unnaturally high silt load moving through the channel immediately post-works. Winter floods and routine maintenance over two years should scour out most such materials. Observations by the author indicate that in drained channels with gradient values between $0.16 \%$ and $0.4 \%$ natural recovery of channel morphology is evident, though not complete, in shallow $(<1.0 \mathrm{~m})$ gravel/stony bed sections two years after works with the reformation of a limited thalweg and a riffle/glide/pool sequence (O'Grady, unpublished data). At this stage one can see how such channel beds are evolving morphologically and design a physical enhancement scheme to accelerate this natural process and identify and correct imbalances.

\section{5b. Pilot Enhancement Pro- grammes}

In large catchments post-drainage enhancement programmes may involve considerable expenditure. It is therefore desirable that pilot experimental and control sites be established and monitored to ensure that particular exercises will be productive in specific circumstances. In Irish rivers the relative success or failure of such programme has been evident in most cases only one year after the completion of the physical works stage even though optimum stocks of salmonids may not colonise such areas for 3 to 5 years after the works stage (O'Grady et al., 1991 and O'Grady et al. 1993). The importance of monitoring the effectiveness of enhancement programmes to assess their value in monetary terms is self evident. Also the usefulness of doing such so that one can develop new designs where original programmes failed should not be overlooked.

\section{5c. In-stream and Bankside Phy- sical Enhancement Exercises}

The type of physical in-stream enhancement exercises undertaken in Irish rivers and the relative success of some of these programmes have been outlined in a number of publications (O'Grady, 1989, 1991(a), 1991(b), 1991(c), O'Grady et al., 1991 and O'Grady et al. (1993)). This investigative programme is ongoing at the present time. The range of structures and materials used and their design functions are summarised here. 
Loose stone "flooded" weirs have been built to perform three different functions - to trap and accumulate gravels for spawning purposes, to create a hydraulic gradient at intervals in low grade $(<0.5 \%)$ channels thereby improving the quality of juvenile salmon and adult trout habitat and to alter uniform glides in high gradient $(>0.3 \%)$ zones generating a riffle/glide/pool sequence. Productive salmonid habitat in deep $(1.0 \mathrm{~m}$ $2.5 \mathrm{~m}$ ) glides with a poor gradient $<0.05 \%$ ) have been created by placing stone mattresses on channel beds which reduce the discharge area at summer level thereby increasing water velocities and creating a more complex ecological regime. The stone bed and increased discharge regime have created quality salmonid habitat (O'Grady et al., 1991). In deep (2.0 m$2.5 \mathrm{~m}$ ) channels these mattresses have been flat in section. In shallower channels $(1.0-1.5 \mathrm{~m})$ gulleys have been built into these structures in central positions to scour pools downstream of the mattresses. Large boulders have been placed on the bed in these pool areas to provide lies for adult trout. Deflectors built in alternaing sequence along a channel have been constructed to restore natural channel base width, thereby increasing vertical scour and recreating a thalweg. These have been constructed of loose stone or timber. In the latter case the frames have been constructed of forestry poles and the structure filled with light branches as described by (White and Bryndilson, 1967 and others). Mid-stream V shaped (islands) structures have been built in shallow glides to mean summer flow level to constrict the summer discharge regime thereby increasing velocities and enhancing salmonid stocks (O'Grady et al., 1991). Bank protection works may have to be incorporated into these programmes. Gravel beds have been reintroduced as necessary where spawning imbalances are evident. The range and mixture of stone sizes used for salmon and trout spawning beds are based on the findings of Fluskey (1989) who established the preferred range of stone sizes in redds dug by salmon and trout in Irish rivers. Areas of river bed with a hard compacted or smooth rock bed have been covered with a layer of rubble to increase macroinvertebrate production (Needham, 1969) and provide a more complex hydraulic regime suited to juvenile salmonids. This strategy has also proved successfull (O'Grady et al., 1993). The fast rate and extent of recolonisation of "new" stony areas by macroinvertebrates in Irish rivers has been described by Lynch and Murray (in press). The impact of excessive bankside vegetation in shading channels and reducing salmonid stocks has been recognised and is being addressed (O'Grady, 1993). The authors are aware of the potential value of "lunker structures" and "1/2 logs" used widely in North America to increase the adult trout carrying capacity of channels (White and Bryndilson, 1967 and others). To-date, we have not had an opportunity to evaluate these in Irish rivers. In general 
the authors have been guided by the extensive literature on trout stream enhancement programmes in North America since the 1930's (Duff, 1988 and others). Some adaptation of the American techniques have been necessary to take account of the specific ecology of Irish systems and to make allowance for the fact that, on most cases, we were dealing with mixed atlantic salmon and brown trout populations.

A degree of pragmatism is required in approaching rehabilitation programmes. Drainage requirements or channel conditions post-drainage may prohibit one from undertaking meaningful fisheries rehabilitation programmes in certain areas or prevent one from recreating the specific habitat type which was present predrainage. Post-drainage fisheries rehabilitation programmes should always be flexible enough to accommodate and address such difficulties. Fisheries losses in one area can often be offset by improvements in other zones particularly where one is dealing with the overall management of relatively large catchments.

\section{5d. The Cost Effectiveness of Rehabilitation}

Rehabilitation costs will be very variable depending as they do on drainage scheme design requirements, and the quantity and type of materials needed to restore a particular ecotype. A typical example of the type of works undertaken in Irish rivers and the benefits which have accrued in fisheries terms are presented (table 1).

Some aspects of the costs and returns presented in Table 1 require elaboration. On the costs side the design expenditure figure is generous. This facet would cost less if the channel are in question was being enhanced as part of a programme for an overall subcatchment. The return data are minimal figures. For instance one could also make some allowance for the added value in trout and salmon tourist angling terms as a consequence of the increased fish stocks. There are also social as well as monetary gains - a functional salmonid stream is a valuable local amenity. The annual fish production

Table 1. - An example of the costs and benefits of salmonid stream enhancement programmes in Ireland

Capital costs

Materials - 1,000 tonne stone/gravel Machine Hire (80 hrs. @ ₹ 18/hr.) Design and Supervisory Costs

TOTAL

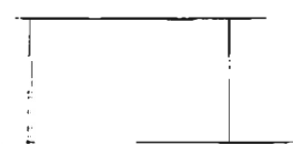

Benefits - Measured in terms of annual fish production post-works

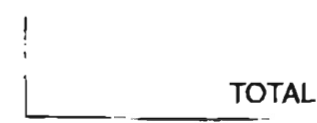

$\begin{array}{r}i \\ 1 \\ 1 \\ \hline\end{array}$

\begin{tabular}{|c|c|c|}
\hline$\{4,500$ & $500 \mathrm{~S}^{2}$ Smolts & $£ 1,500$ \\
\hline$£ 1,440$ & $100 \mathrm{~S}^{\prime}$ Smolts & \& 200 \\
\hline \multirow{3}{*}{$£ 2,000$} & 1,0001 Y.O. trout & 400 \\
\hline & 6002 Y.O. trout & 840 \\
\hline & 3003 Y.O. trout & 600 \\
\hline & TOTAL & c 3540 \\
\hline
\end{tabular}


figures are very conservative estimates of the increases which might be achieved. Significantly higher values have been noted at a number of sites in the Boyne catchment in as little as 2 years after works (O'Grady, unpublished). In addition the figures provided take no account of the large numbers of salmonid fry which are likely to be surplus to the carrying capacity of the section. Some of these young fish will emigrate and are likely to colonise other channel areas. The value of the fish produced were calculated on the following basis. It was assumed that the production costs of a fish farm smolt was $£ 1.00$. It has been established that there is three to four fold difference in the proportion of wild smolts which return as adult salmon compared to farm reared fish (Mills \& Piggins, 1983). Consequently the commercial value of the former type is $£ 3-£ 4$ per fish. Similarly there is a significantly greater survival of wild trout compared to stocked fish. For the purposes of this calculation the differential in survival was calculated at $100 \%$. The value of the wild trout produced are therefore calculated at twice the current fish farm production costs. This too is a conservative figure (O'Grady, 1981). Despite the very conservative basis of calculation in this case it is clear that, in terms of fish production alone, there is a complete return on investment in as little as five years i.e. an allowance is made for a slow initial colonisation rate. Monitoring of some enhanced sites indicate that this is a generous allowance.
Post-drainage in-stream and riparian enhancement programmes result in complex ecological change over time of benefit to water quality, fisheries, wildlife and general conservation interests. Therefore a simple cost benefit in fisheries terms for a specific site falls far short of describing the full benefits.

\section{THE DRAINAGE MAINTENANCE MANAGEMENT AREA}

Many of Ireland's catchments have now been drained and thereafter, in the longterm, must be maintained. Currently there is very little information available to indicate the ways and extent to which such programmes affect fisheries. In 1990 the O.P.W. in conjunction with the Central Fisheries Board have commenced a five years research programme to study this area (O'Grady and King 1991 and 1992a). This exercise is being funded by O.P.W. The objectives are to study a wide range of specific site types in channels which normally require maintenance and, following works, monitor the effects on fish stocks. This will involve the "creation" of experimental and control zones in each habitat type to review the effects of a standard maintenance exercise relative to both unmaintained areas and zones where an alternate maintenance approach is adopted. It is hoped that this programme will enable 
O.P.W. to provide guidelines for staff in relation to maintenance procedures for specific channel types which limit ecological change of value to fisheries and wildlife.

\section{POSITIVE AND NEGATIVE IMPACTS OF DRAINAGE AND LESSONS LEARNED}

As one would expect the initial impact of arterial drainage on Irish salmonid streams was very serious with at least a temporary collapse of salmonid populations (Toner et al., 1965, Kennedy, 1980, McCarthy, 1977 and 1983 and O'Grady unpublished). A review by the author of the only two sites which had been evaluated in detail pre- and immediately post-drainage many years later (21 an 30 years respectively) has illustrated a complete recovery in relation to their general ecology and, in particular, their capacity to support salmonid stocks (O'Grady, 1991(b) and O'Grady and King, 1992(b)). The findings in relation to the two zones in question probably reflect the situation in many channel sections of similar gradient $(0.08 \%)$ where significant quantities of gravel and rubble eroded from the banks post-drainage recreating the predrainage channel bed morphology and where fencing, post-drainage, accommodated the re-establishment of a healthy riparian zone. Brookes (1992) has also noted a tendency for channels, particularly of median power $\left(35 \mathrm{Wm}^{-2}\right)$, in Britain to recover post-drainage in a physical sense. Survey data compiled by the authors indicate that a failure of specific channel sections to recover post-drainage in fisheries terms can generally be related to the absence of a riffle/glide/pool sequence and/or any unbalanced riparian zone (excessive bankside vegetation or none at all).

The physical nature of works programmes which involved lowering river bed levels, thereby creating high banks, has meant that anglers must now fish while standing in the channel rather than standing on the banks.

The author has had the opportunity of assessing the effects of draining whole catchments on atlantic salmon populations by comparing fluctuations in salmon numbers in two such drained watersheds with adjacent undrained systems for a period of years pre-, during and post-drainage. Data indicate no relative change in salmon numbers in one case and a relative increase in salmon numbers postdrainage in the second drained watershed compared to the undrained adjacent watersheds (O'Grady, 1991(a) and O'Grady et al. 1993). Many individual factors played a part in preventing the collapse of the salmon populations in two of the aforementioned systems. They included the positive effect of removing a series of large weirs which had been ponding one system for 150 years, the removal of the natural bedrock protrusions which also ponded channels, a significant increase in the length of gravelled channels exposed by drainage works, extensive post- 
drainage rehabilitation programmes and other factors. The authors would not suggest that the findings in relation to these two catchments necessarily reflect the effects of drainage on all Irish salmonid catchments.

One of the most important lessons learned by the authors in relation to these statistics is that the removal of structures, natural or man made, which are ponding significant lengths of channel can of itself significantly increase the salmonid productivity of rivers in specific circumstances.

This paper illustrates the complexity of issues to be faced if one is to give serious consideration to limiting the impact of drainage works on fisheries and shows the extent to which an interdisciplinary bio-engineering approach is a pre-requisite to achieving ones objectives.

\section{REFERENCES}

Binns N.A., 1982. Habitat quality index procedures manual. Wyoming Game and Fish Department.

Boon P.J., Callow P. and Petts G.E., 1992. River conservation and management. Wiley and Sons, Chichester.

Brookes A., 1987. River channel adjustments downstream from channelization works in England and Wales. Earth Surface Processes and Landforms, 12, 337-351.

Brookes A., 1992. Recovery and restoration of some engineered British river channels. In : River Conservation and Management, Ed. Boon, P.J. Calow, P. and Petts G.E.
Caffrey J., 1990. The classification, ecology and dynamics of aquatic plant communities in some irish rivers. Ph.D. Thesis, National University of Ireland.

C.E.C (Council of the European Communities), 1978. Council directive of July 18 th, 1978 on the quality of freshwaters needing protection or improvement in order to support fish life. (78/659/EEC). Official Journal of the European Communities, No. L222/1.

Cupp C.E., 1989a. Identifying spatial variability of stream characteristics through classification. MS Thesis, University of Washington, Seattle.

Cupp C.E., 1989b. "Stream corridor classification for forested lands of Washington". Washington Forest Protection Association, Olympia, Washington.

Darnell R.M., 1978. Dredge and fill, dams, dykes and channelisation. In: Proc. National Wetland Protection Symposium, Restin, Virginia, June 1977.

Duff D., 1988. Indexed bibliography of stream habitat,improvement. U.S.D.A. Forest Service Intermountain Region Wildlife Management Staff.

Fluskey R., 1989. An analysis of the gravels used by spawning salmonids in Ireland. Ir. Fish. Invest. Series A (Freshwater) No. 32.

Hermansen $\mathrm{H}$. and Kregs C., 1984. Influences of physical factors on density of stocked brown trout (Salmo trutta fario L.) in a Danish lowland stream. Fish. Mgmt. 15, No. 3, 107-115.

Howard J. 1993. Drainage, flood relief and river management. In: Water is Life Conference, Royal Dublin Society, Ed. C. Mollan.

Hynes H.B.N., 1970. The ecology of running waters. Liverpool University Press.

Karr J.R. and Schlosser I.J., 1978. Water resources and the land-water interface. Science, 201, 229-234. 
Kennedy G., 1980. Drainage related changes in salmonid and invertebrate populations in the River Camowen. Proceedings of the Institute of Fisheries Management Conference, Magee University College, 63-68.

Lynch J.M. and Murray D.A. In Press. Fishery rehabilitation and habitat enhancement following arterial drainage in Ireland. XXV Sil Congress, Barcelona, August, 1992.

McCarthy D.T., 1977. The effects of drainage on the Trimblestown River 1. Benthic invertebrates and flora. Ir. Fish. Invest., A 16, 1-16.

Mc Carthy D.T., 1983. The impact of arterial drainage on fish stocks in the Trimblestown River. In: Advances in Fish Biology in Ireland. Ed. C. Moriarity. Ir. Fish. Invest. A. 23, 16-19.

Mills C. and Piggins D., 1983. The release of reared salmon smolts (S. salar L.) into the Burrishoole River system and their contribution to the rod and line fishery. Fish. Mgmt., 14, No. 4, 165175.

Needham P.R., 1969. Trout streams Revised by C.F. Bond Winchester Press, New York.

O'Grady M.F., 1981. A study of brown trout (S. trutta L.) populations in selected Irish lakes. Ph.D. Thesis, National University of Ireland.

O'Grady M.F., 1989. Rehabilitation of the Boyne. The Engineers Journal, March, 1989.

O'Grady M.F., 1991(a). Rehabilitation of salmonid habitats in a drained Irish river system. In: Steer M.W. (ed.) Biology and Management of Irish Rivers, R.I.A., Dublin, 187-204.

O'Grady M.F., 1991(b). Ecological changes over 21 years caused by drainage of a salmonid stream, the Trimblestown River. Ir. Fish. Invest., $\boldsymbol{A}$ (Freshwater), No. 33, 1-10.

O'Grady M.F., 1991(c). Assessing the impact of a proposed riverine drainage programme from the fisheries perspec- tive. In : E.I.A. for public projects. Institution of Engineers of Ireland.

O'Grady M.F. (1993). Initial observations on the effects of varying levels of deciduus bankside vegetation on saimonid stocks in Irish waters. Aquaculture and Fisheries Management, 24, 563573.

O'Grady M.F. and Caffrey J., 1984. A survey of fish stocks in the River Suir catchment (1982/83). Internal Report, Central Fisheries Board.

O'Grady M.F.and King J.J., 1992. An experimental drainage maintenance programme (Year 1). A report commissioned by the Otfice of Public Works.

O'Grady M.F. and King J.J., 1992(a). A experimental drainage maintenance programme (Year 2). A report commissioned by the Office of Public Works.

O'Grady M.F. and King J.J., 1992(b). Ecological changes over 30 years caused by drainage of a salmonid stream, the Bunree River. Ir. Fish. Invest. Ser. A (Freshwater) No. 34, 16 pp.

O'Grady M.F., King J.J. and Curtin J., 1991. The effectiveness of two physical instream works programmes in enhancing salmonid stocks in a drained Irish lowland river. In: Mills D. (ed.) Strategies for the rehabilitation of salmon rivers. Atlantic Salmon Trust, Institute of Fisheries Managements and Linnean Society of London, 154-178.

O'Grady M.F., King J.J. and Corbett K. 1993. The ecological impact of drainage scheme design on salmonid stocks in the River Bonet with particular reference to newly created shallow areas. In: Mollan C. (ed.) Water is Life, R.I.A., Dublin.

Petersen R.C., Petersen L.B-M., Lacoursiere J., 1992. A building-block model for stream restoration. In : Boon P.J., Calow P. and Petts G.E. (ed.), River Conservation and Management.

Rosgen D.L., 1985. "A stream classification system", In : Johnson R.R., Zeibell 
C.D., Patton D.R., Pfolliot F. and Hamre R.H. (ed.) Riparian Ecosystems and their Management : Reconciling Conflicting Uses, pp. 91-95, United States Forest Service, General Technical Repot M-120, Rocky Mountain Forest and Range Experimental Station, Fort Collins, Colorado.

Toner E.D., O'Riordan A. and Twomey E., 1965. The effects of arterial drainage works on the salmon stock of a tributary of the R. Moy. Ir. Fish. Invest. Ser. A, No. 1.

Waters T.F., 1968. Diurnal periodicity in the drift of a day-active stream invertebrate. Ecology, 49 (1), 152-153.

Whelan B.J. and Marsh G., 1988. An economic evaluation of Irish angling. Central Fisheries Board.
White R.J. and Brynildson O.M., 1967. Guidelines for management of trout stream habitat in Wisconsin. Technical Bulletin No. 39, Department of Natural Resources Division of Conservation, Madison, Wisconsin 53701.

\section{ACKNOWLEDGEMENTS}

The authors wish to thank all of their colleagues in the office of Public Works and the Central and Regional Fisheries Boards who assisted this programme. The studies were funded by the Office of Public Works. We are grateful to Mr. J. Howard (O.P.W.) and Dr P. Fitzmaurice (C.F.B.) for editorial comment. 